\title{
Bioefficacy of entomopathogenic mycoformulations and effect of adjuvants against nymphs of cabbage aphid, Brevicornye brassicae (Linnaeus)
}

\section{Karuna Thakur*}

Department of Microbiology, College of Basic Sciences and Humanities, Punjab Agricultural University, Ludhiana (Punjab), India

\section{Neelam Joshi}

Department of Entomology, College of Agriculture, Punjab Agricultural University, Ludhiana, 141004 (Punjab), India

\section{Sudhendu Sharma}

Department of Entomology, College of Agriculture, Punjab Agricultural University, Ludhiana, 141004 (Punjab), India

*Corresponding author. E. mail: karunathakur2108@gmail.com

\section{Article Info}

https://doi.org/10.31018/ jans.v13i2.2653

Received: April 2, 2021

Revised: May 11, 2021

Accepted: May 18, 2021

\section{How to Cite}

Thakur, K. et al. (2021). Bioefficacy of entomopathogenic mycoformulations and effect of adjuvants against nymphs of cabbage aphid, Brevicornye brassicae (Linnaeus). Journal of Applied and Natural Science, 13(2), 530 - 536. https://doi.org/10.31018/ jans.v13i2.2653

\begin{abstract}
Cabbage aphid, Brevicornye brassicae (Linnaeus) is one of the major insect pests of cabbage. Chemical control is mostly used to manage this pest. The present investigation was conducted to evaluate an environmentally benign approach for the pest management through different entomopathogenic mycoformulations against nymphs of $B$. brassicae to identify effective mycoformulation. The effect of mycoformulations supplemented with different adjuvants against nymphs of $B$. Brassicae was also evaluated under laboratory conditions. The bioassay studies of fungal bioformulation against nymphs of $B$. brassicae recorded maximum cumulative per cent mortality (53.33\%) in talc formulation of $L$. lecanii MTCC 956 and commercial $L$. Lecanii formulation @12 $\mathrm{g} \mathrm{L}^{-1}$ and these were at par with each other. Maximum percent reduction of nymphal population over control 54.66 and 51.33 per cent was recorded @12 $\mathrm{g} \mathrm{L}^{-1}$ in talc formulation of $L$. lecanii (MTCC 956) and commercial $L$. Lecanii formulation ten days after treatment respectively. Laboratory studies undertaken to evaluate talc formulation of $L$. lecanii MTCC 956 lecanii with and without adjuvants against the nymphs of $B$. brassicae recorded maximum percent increase in mortality over control $(7.89 \%)$ in $L$. lecanii formulation + tween80@1\%. Results of this study signified that $L$. lecanii formulation, when supplemented with adjuvants enhanced the growth of $L$. lecanii and increased mortality of nymphs of $B$. brassicae and could be used as a part of the integrated pest management program.
\end{abstract}

Keywords: Brevicornye brassicae, Entomopathogenic fungi, Lecanicillium lecanii, Tween 80

\section{INTRODUCTION}

Cabbage (Brassica oleracea var. Capitate) of family Brassicaceae is an important vegetable crop and India ranks second in producing 9192 thousand metric tons of cabbage from the area of 403 thousand/ha. Punjab produces 97.8 thousand metric tonnes of cabbage from an area of 5.6 thousand/ha (Horticulture Statistical Division, 2018). It is a cool weather crop with an optimum growth temperature of $18^{\circ} \mathrm{C}$. It is a rich source of vitamin $\mathrm{K}, \mathrm{C}, \mathrm{B}_{6}, \mathrm{~B}_{12}$ and contains various anticancer and antioxidant compounds (Abed and Simon 2015). It is infested by various pests and pathogens, leading to damage and low yield, which affects the economy of the farming community. The major insect pests of cabbage are Plutella xylostella (Linnaeus), Spodoptera litura (Fabricius), Brevicornye brassicae (Linnaeus) and Pieris brassicae (Linnaeus), which account for total damage up to 80 per cent in the nurseries and up to $25 \%$ in the field crop. About $30-35 \%$ of crop has been reported to be damaged due to pests and diseases each year in India (Yadav and Kumar, 2021). The cabbage aphid $B$. brassicae is an important sucking pest of greenhouse and field crops all over the world. They are greyish-green with a waxy covering composed of lipopolysaccharides and have short cor- 
nicles through which they feed on the underside of leaves in large clusters or in the centre of cabbage heads. The aphid penetrates the leaves, stem and feeds on the plant phloem sap. Reduction of crop yield due to their infestation causes severe economic losses. It reduces plant growth by 35 percent and the yield loss of the plant by 85 percent (Strauss et al., 2002).

Apart from health hazards the repercussions of using extensive pesticides have environmental impacts, resistance against pests and also have harmful effects on non-target organisms (Sharma et al., 2017). So, to overcome these problems, alternate methods are required and biocontrol by entomopathogenic fungi is one of the widely exploited methods for the control of various pests. The entomopathogenic fungi cause disease and death of crop insect and contribute to regulating their population (Ahmed et al., 2016). These fungal pathogens play a vital role in controlling the population of economically important insects. This makes mycoformulations an important insect pest control agents (Maina et al., 2018).

Entomopathogenic fungi found in the field under natural conditions cause lethal infections and regulate insect population in nature by epizootics (Asi et al., 2009). The efficiency of entomopathogens in the field depends upon virulence towards target pest, coverage and persistence on target site. However, the major constrains for the successful use of these bioagents is loss of virulence by UV rays, shorter shelf life and dependability on environmental conditions. To overcome these problems, adjuvants were used which may enhance the growth development and viability of the fungus, they may play a role as nutrients, adhesive, UV protectants or wetting agents etc. (Lopes et al., 2011; Barreto et al., 2016). Adjuvants like spreaders, stickers and UV protectants used may increase the efficacy of entomopathogenic fungus. The present study was undertaken to identify virulent entomopathogenic mycoformulations and evaluate different adjuvants supplemented in potential mycoformulation against nymphs of $B$. brassicae.

\section{MATERIALS AND METHODS}

\section{Source of fungal culture}

Two Lecanicillium lecanii isolates (MTCC 956 and MTCC 2056) procured form Institute of Microbial Technology (CSIR- IMTECH), Chandigarh; one Metarhizium anisopliae isolates (NBAIR M-35) procured from National Bureau of Agricultural Insect Resources (NBAIR), Bengaluru, one Beauveria bassiana (Bb-B1) native isolate of our biocontrol laboratory, were used in the present study. These isolates were grown and maintained on potato dextrose agar (PDA) (Dextrose 2\%, Potatoes infusion form $20 \%$ and agar $5 \%$, chloramphenicol $0.5 \%$ ) and stored at refrigeration temperature till further use.

\section{Production of mycoformulation}

These fungal isolates were inoculated and incubated on sterilized broken rice grains for 21 days at $\left(25 \pm 2^{\circ} \mathrm{C}\right)$ and formulated to talc formulation according to methodology of (Nirmala et al., 2005).

\section{Test bio pesticides}

Three entomopathogenic mycoformulations viz.BioCatch (L. lecanii $1.50 \%$ liquid formulation, manufactured by T. Stanes \& Company Limited, Tamil Nadu, India), Kalichkra (M. anisopliae1\% WP, manufactured by International Panaacea Ltd (IPL), Connaught Place, New Delhi, India), Daman (B. bassiana $2 \%$ AS, manufactured by T. Stanes \& Company Limited, Tamil Nadu, India were used for the present study.

\section{Evaluation of entomopathogenic mycoformulations against nymphs of $\boldsymbol{B}$. brassicae}

Talc based formulations of $L$. lecanii MTCC 956, $L$. lecanii MTCC 2056, Metarhizium anisopliae (NBAIR, $\mathrm{M}-35)$, Beauveria bassiana $\mathrm{Bb}-\mathrm{B} 1$ along with three commercial entomopathogenic formulations viz BioCatch (L. lecanii 1.5\%), Kalichkra (M. anisopliae1\% WP)Daman (B. bassiana $2 \%$ AS), chemical check Malathion 50 EC and unsprayed control were evaluated for their pathogenicity at different concentrations@ @ 10 and $12 \mathrm{~g} /$ litre against nymphs of $B$. brassicae according to the methodology of Asi et al., (2009) with little modifications. There were twenty three treatments with three replication and twenty nymphs per replica. The cabbage leaves containing nymphs of $B$. brassicae were treated with different concentration of myco-pesticides formulation by spray method. Wet cotton was placed around mid-rib of the leaf to protect it from drying, which was then incubated at room temperature $\left(25 \pm 2^{\circ} \mathrm{C}\right)$ petri plate. Cumulative per cent mortality was recorded on $3^{\text {rd }}$, 5th, 7 th and $10^{\text {th }}$ days after treatment. The data was analysed by using ANOVA.

\section{Efficacy of entomopathogenic fungal formulation supplemented with adjuvants against nymph of $B$. brassicae}

Potential L. lecanii MTCC 956 bioformulation was separately supplemented with various adjuvants at different concentrations as Tween®-80 (@ 0.1, 0.5 and 1\%), Glycerol (@ 2, 5 and 8 \%), Ranipal (@0.1, 0.2 and 1\%) SDS (@ 1, 2.5 and 5 \%), CMC (@ 0.2, 0.5 and 1\%). There were sixteen treatments and three replications per treatment and twenty nymphs per replica. The cumulative percent mortality over control ( $L$. lecanii without adjuvants) was recorded 10 days after treatment. 
Per cent increase in mortality was calculated as:

Per cent increase in mortality $=\frac{T_{a d}-T_{w a d}}{T_{w a d}} \times 100$ Eq. 1

$\mathrm{T}_{\mathrm{ad}} \quad=$ mortality in entomopathogenic fungi is supplemented with adjuvant

$\mathrm{T}_{\text {wad }}=$ mortality recorded in no. of aphids when no adjuvant is supplemented in entomopathogenic fungi.

\section{RESULTS AND DISCUSSION}

The cumulative percent mortality of mycoformulations ranged from 28.33 to 56.66 per cent ten days after treatment. Maximum percent mortality $(56.66 \%)$ was recorded for $L$. lecanii MTCC 956 (@12g/l) which was statistically at par with L. lecanii MTCC 956 (@10g/l) and M. anisopliae NBAIR M-35 (@12g/l) and recorded (53.33\%) and (48.33\%) respectively (Table1). Minimum percent mortality (28.33\%) and $(30.00 \%)$ was recorded in $B$. bassiana $\mathrm{Bb}-\mathrm{B} 1$ and L. lecanii MTCC 2056 respectively and were at par with each other However, chemical check Malathion 50 EC (@4ml/l) recorded 93.33 per cent mortality. The maximum nymphal population per cent reduction over control $(54.66 \%)$ was in treatment L. lecanii MTCC 956 (@12g/l) after $10^{\text {th }}$ day and lowest $(24.56 \%)$ was recorded in $B$. bassiana. Further, with an increase in concentration mortality also increased (Fig. 1).

L. lecanii MTCC 956 formulation was separately supplemented with different adjuvants and evaluated against nymphs of $B$. brassicae. Maximum cumulative per cent mortality $(68.33 \%)$ was recorded in $(L$. lecanii + tween80@1\%)which was at par with ( $L$. lecanii + glycerol @ 8\%) and (L. lecanii + SDS@ @\%) with 66.6 per cent mortality ten days after treatment (Table2).However, minimum per cent mortality (38.33\%) was recorded in (L. lecanii+ Ranipal @0.1\%) and (L. lecanii + CMC (@0.2\%). Maximum per cent increased in mortality over control ( $L$. lecanii without adjuvants)(7.89\%) was recorded in ( $L$. lecanii + tween80@1\%). This was followed by ( $L$. lecanii + glycerol @8\%) and (L. lecanii + SDS @ $5 \%$ ) which

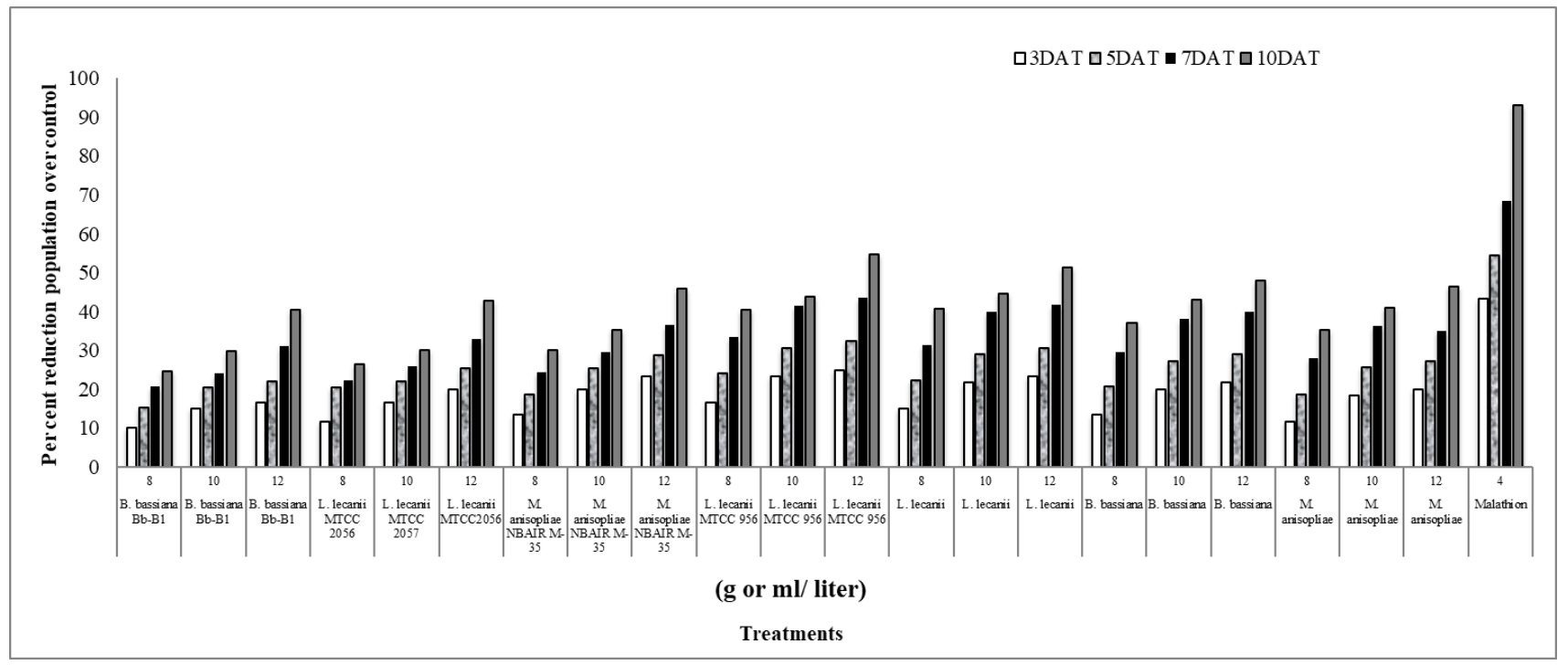

Fig. 1. Efficacy of mycoformulations against nymphs of $B$. brassicae

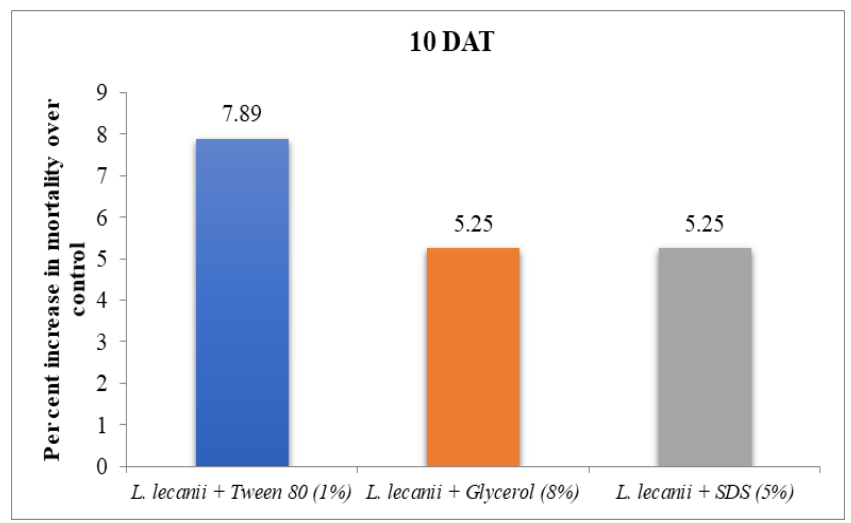

Fig. 2. Efficacy of L. lecanii MTCC956 with adjuvants against nymphs of $B$. brassicae. were at par with each other and recorded 5.25 per cent increase in mortality over control. (Fig.2). However, no increase in mortality over control was recorded in $(L$. lecanii + Ranipal @ 1\%) and (L. lecanii + CMC @ 1\%). Similarly, Keridis (2016) investigated the pathogenicity of various entomopathogenic fungi viz $M$. anisopliae, $B$. bassiana and $V$. lecanii against cabbage aphid and recorded per cent mortalities ranging between 80.0 to $100,62.0$ to 83.0 and 65.0 to $85.0 \%$ with V. lecanii, $M$. anisopliae and $B$. bassiana, respectively ten days after treatment and reported that among all fungi, $V$. lecanii was most potential. Singh and Joshi (2020) also evaluated biorationals against sucking pests of capsicum under protected conditions and reported $L$. lecanii 
Thakur, K. et al. / J. Appl. \& Nat. Sci. 13(2), 530 - 536 (2021)

Table 1. Bio-efficacy of entomopathogenic fungal formulations against nymphs of Brevicornye brassicae under laboratory conditions.

\begin{tabular}{|c|c|c|c|c|c|}
\hline \multirow{3}{*}{ T̄reatments } & \multirow{3}{*}{$\begin{array}{l}\text { Conc. } \\
(\mathrm{g} / \mathrm{l}) \text { or }(\mathrm{ml} / \mathrm{l})\end{array}$} & \multicolumn{4}{|c|}{ Per cent mortality } \\
\hline & & \multicolumn{4}{|c|}{ Days of Observations } \\
\hline & & $\overline{3^{\text {rd }}}$ & $5^{\text {th }}$ & $7^{\text {th }}$ & $10^{\text {th }}$ \\
\hline \multirow{3}{*}{$\begin{array}{l}\text { Beauveria bassiana } \\
\text { (Bb- B1) } \\
1 \times 10^{8} \mathrm{CFU} / \mathrm{ml}\end{array}$} & 8 & $\begin{array}{l}10.00^{c} \\
(18.04)\end{array}$ & $\begin{array}{l}16.66^{c} \\
(24.03)\end{array}$ & $\begin{array}{l}23.33^{d} \\
(28.84)\end{array}$ & $\begin{array}{l}28.33^{d} \\
(32.12)\end{array}$ \\
\hline & 10 & $\begin{array}{l}15.00^{\mathrm{c}} \\
(22.58)\end{array}$ & $\begin{array}{l}21.66^{c} \\
(27.69)\end{array}$ & $\begin{array}{l}26.66^{\text {cd }} \\
(31.05)\end{array}$ & $\begin{array}{l}33.33^{d} \\
(35.23)\end{array}$ \\
\hline & 12 & $\begin{array}{l}16.66^{\mathrm{bc}} \\
(23.84)\end{array}$ & $\begin{array}{l}25.00^{\mathrm{bc}} \\
(29.91)\end{array}$ & $\begin{array}{l}33.33^{c d} \\
(35.20)\end{array}$ & $\begin{array}{l}43.33^{c} \\
(41.13)\end{array}$ \\
\hline \multirow{3}{*}{$\begin{array}{l}\text { Lecanicillium lecanii } \\
\text { (MTCC } 2056) \\
\left(1 \times 10^{8} \mathrm{CFU} / \mathrm{ml}\right)\end{array}$} & 8 & $\begin{array}{l}11.66^{c} \\
(19.49)\end{array}$ & $\begin{array}{l}18.33^{\mathrm{c}} \\
(25.29)\end{array}$ & $\begin{array}{l}25.00^{d} \\
(29.98)\end{array}$ & $\begin{array}{l}30.00^{d} \\
(33.19)\end{array}$ \\
\hline & 10 & $\begin{array}{l}16.66^{\mathrm{bc}} \\
(24.03)\end{array}$ & $\begin{array}{l}23.33^{c} \\
(28.84)\end{array}$ & $\begin{array}{l}28.33^{c d} \\
(32.12)\end{array}$ & $\begin{array}{l}33.33^{d} \\
(35.23)\end{array}$ \\
\hline & 12 & $\begin{array}{l}20.00^{b c} \\
(26.43)\end{array}$ & $\begin{array}{l}26.66^{\mathrm{bc}} \\
(30.98)\end{array}$ & $\begin{array}{l}35.00^{\mathrm{c}} \\
(36.22)\end{array}$ & $\begin{array}{l}45.00^{c} \\
(42.10)\end{array}$ \\
\hline \multirow{3}{*}{$\begin{array}{l}\text { Metarhizium anisopliae } \\
\text { (NBAIR M-35) } \\
\left(1 \times 10^{8} \mathrm{CFU} / \mathrm{ml}\right)\end{array}$} & 8 & $\begin{array}{l}13.33^{c} \\
(20.74)\end{array}$ & $\begin{array}{l}20.00^{c} \\
(26.43)\end{array}$ & $\begin{array}{l}26.66^{c d} \\
(31.05)\end{array}$ & $\begin{array}{l}33.33^{d} \\
(35.23)\end{array}$ \\
\hline & 10 & $\begin{array}{l}20.00^{b c} \\
(26.43)\end{array}$ & $\begin{array}{l}26.66^{\mathrm{bc}} \\
(31.05)\end{array}$ & $\begin{array}{l}31.66^{c} \\
(34.21)\end{array}$ & $\begin{array}{l}38.33^{c d} \\
(38.22)\end{array}$ \\
\hline & 12 & $\begin{array}{l}23.33^{b c} \\
(28.84)\end{array}$ & $\begin{array}{l}30.00^{\mathrm{bc}} \\
(33.14)\end{array}$ & $\begin{array}{l}38.33^{b c} \\
(38.17)\end{array}$ & $\begin{array}{l}48.33^{b c} \\
(44.01)\end{array}$ \\
\hline \multirow{3}{*}{$\begin{array}{l}\text { Lecanicillium lecanii } \\
\text { (MTCC } 956) \\
\left(1 \times 10^{8} \mathrm{CFU} / \mathrm{ml}\right)\end{array}$} & 8 & $\begin{array}{l}16.66^{\mathrm{bc}} \\
(23.73)\end{array}$ & $\begin{array}{l}25.00^{\mathrm{bc}} \\
(29.78)\end{array}$ & $\begin{array}{l}35.00^{\mathrm{c}} \\
(36.16)\end{array}$ & $\begin{array}{l}43.33^{c} \\
(41.13)\end{array}$ \\
\hline & 10 & $\begin{array}{l}23.33^{b c} \\
(28.76)\end{array}$ & $\begin{array}{l}31.66^{\mathrm{bc}} \\
(34.13)\end{array}$ & $\begin{array}{l}43.13^{b} \\
(41.13)\end{array}$ & $\begin{array}{l}53.33^{\text {bc }} \\
(46.90)\end{array}$ \\
\hline & 12 & $\begin{array}{l}25.00^{\mathrm{b}} \\
(29.98)\end{array}$ & $\begin{array}{l}33.33^{\mathrm{b}} \\
(35.23)\end{array}$ & $\begin{array}{l}45.00^{\mathrm{b}} \\
(42.07)\end{array}$ & $\begin{array}{l}56.66^{\mathrm{b}} \\
(49.01)\end{array}$ \\
\hline \multirow{3}{*}{$\begin{array}{l}\text { Lecanicillium lecanii } \\
\text { (Commercial) } \\
\left(1 \times 10^{8} \mathrm{CFU} / \mathrm{ml}\right)\end{array}$} & 8 & $\begin{array}{l}15.00^{\mathrm{c}} \\
(22.28)\end{array}$ & $\begin{array}{l}23.33^{\mathrm{c}} \\
(28.76)\end{array}$ & $\begin{array}{l}33.33^{\mathrm{cd}} \\
(35.20)\end{array}$ & $\begin{array}{l}43.33^{c} \\
(41.13)\end{array}$ \\
\hline & 10 & $\begin{array}{l}21.66^{b c} \\
(27.50)\end{array}$ & $\begin{array}{l}30.00^{\mathrm{bc}} \\
(33.14)\end{array}$ & $\begin{array}{l}41.66^{b c} \\
(40.18)\end{array}$ & $\begin{array}{l}46.66^{\mathrm{c}} \\
(43.06)\end{array}$ \\
\hline & 12 & $\begin{array}{l}23.33^{b} \\
(28.65)\end{array}$ & $\begin{array}{l}31.66^{\mathrm{bc}} \\
(34.21)\end{array}$ & $\begin{array}{l}43.33^{b} \\
(41.14)\end{array}$ & $\begin{array}{l}53.33^{\text {bc }} \\
(46.89)\end{array}$ \\
\hline \multirow{3}{*}{$\begin{array}{l}\text { Beauveria bassiana } \\
\text { (Commercial) } \\
\left(1 \times 10^{8} \mathrm{CFU} / \mathrm{ml}\right)\end{array}$} & 8 & $\begin{array}{l}13.33^{c} \\
(21.13)\end{array}$ & $\begin{array}{l}21.66^{\mathrm{c}} \\
(27.69)\end{array}$ & $\begin{array}{l}31.66^{c d} \\
(34.21)\end{array}$ & $\begin{array}{l}40.00^{\text {cd }} \\
(39.21)\end{array}$ \\
\hline & 10 & $\begin{array}{l}20.00^{b c} \\
(26.43)\end{array}$ & $\begin{array}{l}28.33^{b c} \\
(32.12)\end{array}$ & $\begin{array}{l}40.00^{b c} \\
(39.21)\end{array}$ & $\begin{array}{l}45.00^{\circ} \\
(42.11)\end{array}$ \\
\hline & 12 & $\begin{array}{l}21.66^{b c} \\
(27.69)\end{array}$ & $\begin{array}{l}30.00^{\mathrm{bc}} \\
(33.06)\end{array}$ & $\begin{array}{l}41.66^{b c} \\
(40.18)\end{array}$ & $\begin{array}{l}50.00^{\mathrm{bc}} \\
(44.98)\end{array}$ \\
\hline \multirow{3}{*}{$\begin{array}{l}\text { Metarhizium anisopliae } \\
\text { (Commercial) } \\
\left(1 \times 10^{8} \mathrm{CFU} / \mathrm{ml}\right)\end{array}$} & 8 & $\begin{array}{l}11.66^{c} \\
(19.87)\end{array}$ & $\begin{array}{l}20.00^{\mathrm{c}} \\
(26.55)\end{array}$ & $\begin{array}{l}30.00^{\mathrm{cd}} \\
(33.19)\end{array}$ & $\begin{array}{l}38.33^{\text {cd }} \\
(38.22)\end{array}$ \\
\hline & 10 & $\begin{array}{l}18.33^{b c} \\
(25.29)\end{array}$ & $\begin{array}{l}26.66^{b c} \\
(31.05)\end{array}$ & $\begin{array}{l}38.33^{\mathrm{bc}} \\
(38.22)\end{array}$ & $\begin{array}{l}43.33^{c} \\
(41.14)\end{array}$ \\
\hline & 12 & $\begin{array}{l}20.00^{b c} \\
(26.43)\end{array}$ & $\begin{array}{l}28.33^{\mathrm{bc}} \\
(32.12)\end{array}$ & $\begin{array}{l}40.00^{\mathrm{bc}} \\
(39.19)\end{array}$ & $\begin{array}{l}48.33^{b c} \\
(44.02)\end{array}$ \\
\hline $\begin{array}{l}\text { Malathion (50EC) } \\
\text { (Chemical check) }\end{array}$ & 4 & $\begin{array}{l}43 . .33^{a} \\
(41.14)\end{array}$ & $\begin{array}{l}55.00^{a} \\
(47.89)\end{array}$ & $\begin{array}{l}68.33^{\mathrm{a}} \\
(55.83)\end{array}$ & $\begin{array}{l}93.33^{a} \\
(75.21)\end{array}$ \\
\hline Untreated Control & & $\begin{array}{l}0.00^{d} \\
(0.00)\end{array}$ & $\begin{array}{l}1.66^{d} \\
(4.30)\end{array}$ & $\begin{array}{l}3.33^{\mathrm{e}} \\
(8.61)\end{array}$ & $\begin{array}{l}5.00^{\mathrm{e}} \\
(12.91)\end{array}$ \\
\hline$(C D p=0.05)$ & & 6.81 & 5.70 & 5.34 & 5.27 \\
\hline
\end{tabular}

Values in parentheses are arc sine transformations 
MTCC 956 and Azadirachtin 1\% were effective in reducing sucking pest population. Hasan et al. (2013) reported maximum lipolytic activity of $L$. lecanii at $\mathrm{pH} 7$. This could be the reason for the greater efficacy of $L$. Lecanii formulation as it degrades the waxy coating of $B$. brassicae made up of lipopolysaccharides. The germination factor also made $L$. lecanii more virulent as it germinates well under wide range of temperature and humidity. Palande and Pokharkar (2005) evaluated $V$. lecanii against $B$. brassicae under laboratory conditions and reported that an increase in the concentration of $V$. lecanii from $1 \times 10^{3}$ to $1 \times 10^{9} \mathrm{CFU} / \mathrm{ml}$ increased the mortality from 16.3 to $93.3 \%$. Percent increase in mortality in L. lecanii formulation with tween80@1\% may be due to fact that tween 80 being a non-ionic surfactant acts as emulsifier and enhances the fungal growth. Kollmann et al. (2003) reported an increase in spore production by entomopathogenic fungi with non-ionic surfactants; the results obtained by us also support this statement.
Nguyen et al. (2015) optimized conditions for increased chitinase enzyme production and also recorded $25 \%$ increase in chitinase enzyme activity in the presence of tween $20(1-2 \%)$, tween $80(0.5 \%)$ and Triton X-100 (1\%). The addition of tween 20 and tween 80 in media is also associated with enhanced production of extracellular enzymes like lipase, lignase and alpha-amylase (Silva et al., 2005). The surfactants act as an activator for enzyme production and thus resulted in increased mortality by entomopathogenic fungi. As adjuvants are slow to evaporate, they provide enough moisture for the fungus to remain active for a longer period of time and help in the production of good fungal conidia (Kaaya et al., 2011). The surface tension of spray droplet is decreased in the presence of adjuvants which help in improved retention of spray droplet on the plant surface (Somervaille et al., 2012). Joshi and Sangha (2019) evaluated three different isolates of $L$. lecanii with and without mixture of adjuvants (glycerol @8 and tween80@0.5\%) against nymphs of L. erysimi. They

Table 2. Evaluation of $L$. lecanii MTCC 956 supplemented with adjuvants against nymphs of $B$. brassicae under laboratory conditions.

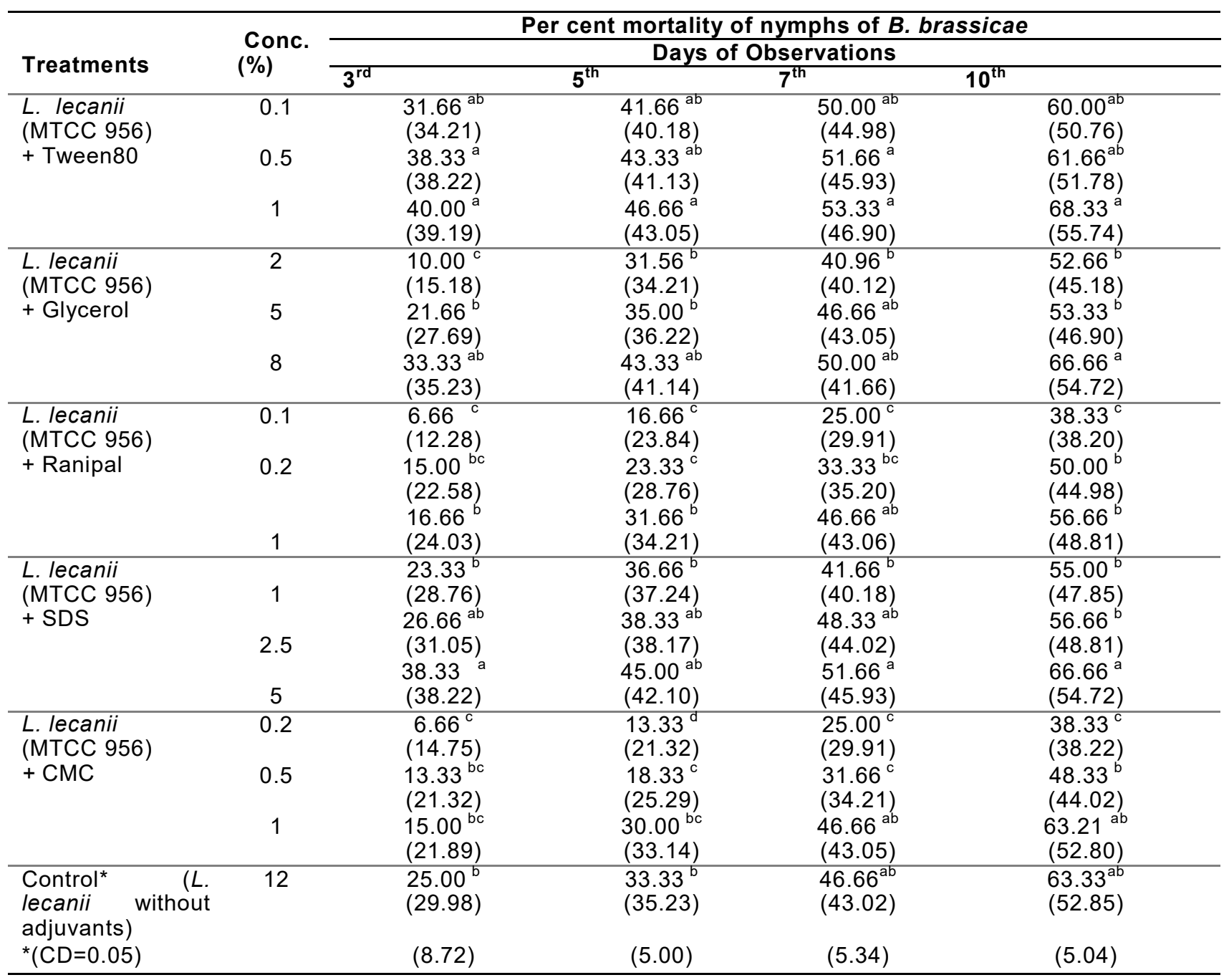

Figures in parentheses are arc sine transformed values; ${ }^{*}$ Control- L. lecanii MTCC 956 without adjuvants 
reported that maximum increase in mortality over control was found to be with adjuvants $(9.80 \%)$ in Lecanicillium lecanii NIPHM followed by Lecanicillium lecanii MTCC 956 (7.77\%), which is similar to our result, i.e. $(7.89 \%)$ when tween80 @ 1\% was added in L. lecanii MTCC 956.

\section{Conclusion}

The present study concluded that among all bioformulations, L. lecanii MTCC 956 (@10 \& 12 g/litre) was effective in reducing nymphal population of $B$. brassicae. Further bioformulation of $L$. lecanii MTCC 956+ tween80@1\% recorded 7.89 per cent increase in mortality over control ( $L$.lecanii without adjuvants). So, $L$. lecanii was found to be more effective due to its high germination factor or chitinase activity and when adjuvants were added, they just stimulate the activity of extracellular enzymes resulting in increasing the efficacy of mycoformulations. These results suggest that these mycoformulations can be adopted in Integrated Pest Management for the control of aphid. However, further field studies and studies on extracellular enzyme activities and their correlation with virulence of these mycoformulations are necessary to generate more information for the management of $B$. brassicae.

\section{ACKNOWLEDGEMENTS}

The authors are thankful to Head, Department of Entomology Punjab Agricultural University, Ludhiana for providing the facility to conduct present experiment.

\section{Conflict of interest}

The authors declare that they have no conflict of interest.

\section{REFERENCES}

1. Abed, M. S. \& Simon, S. (2015). Evaluation of selected botanical extracts against cabbage aphids (Brevicornye brassicae L.) under Allahabad agro climatic conditions. American Multidisciplinary International Research Journal, 2, 23-28.

2. Ahmed, S.S., Saikia, D. K. \& Devee, A. (2016). Efficacy of different IPM modules against major pests of cabbage. Entomon., 41, 189-94

3. Asi, M. R., Bashir, M. H., Afzal, M. \& Imran, S. (2009) .Effect of conidial concentration of Entomopathogenic Fungi on Mortality of Cabbage Aphid, Brevicornye brassicae L. Pakistan Journal of Life and Social Sciences, $2,175-80$

4. Barreto, L. P., Luz, C., Mascarin, G. M., Roberts, D. W., Arruda, W. \& Fernandes, E. K. K. (2016). Effect of heat stress and oil formulation on conidial germination of $\mathrm{Me}$ tarhizium anisopliae s.s. on tick cuticle and artificial medium. Journal of Invertebrate Pathology. 138, 94-103. doi: 10.1016/j.jip.2016.06.007.
5. Hasan. Saba, Ahmad, Anis and Purwar, Abhinav \& Khan, Nausheen and Kundan, Rishi and Gupta Garima (2013). Production of Extracellular enzymes in the entomopathogenic fungus Verticillium lecanii. Bioinformation, 9, 23842

6. Horticulture Statistics Division (2018). Horticulture Statistics Year Book India 2018. Department of Agriculture, Cooperation and Farmers Welfare. Retrieved from www.mospi.nic.in.

7. Kaaya, G. P., Samish, M., Hedimbi, M., Gindin, G. \& Glazer, I. (2011). Control of tick populations by spraying Metarhizium anisopliae conidia on cattle under field conditions. Experimental and Applied Acarology, 55, 273-81

8. Keridis AL A (2016). Virulence of some entomopathogenic fungi on cabbage aphids, Brevicornye brassicae L. International Journal of Chem-Tech Research .9, 61-67.

9. Kollmann, A., Brault, A., Touton, I., Dubroca, J., Chaplain, V. \& Mougin, C. (2003). Impact of nonylphenol surfactants on fungi following the application of sewage sludge on agricultural soils. Journal of Environmental Quality. 32, 1269-76. DOI: 10.2134/jeq2003.1269.

10. Lopes, R. B., Pauli, G., Mascarin, G. M. \& Faria, M. (2011). Protection of entomopathogenic conidia against chemical fungicides afforded by an oil based formulation. Biocontrol Science and Technology. 21, 125-137. doi: https://doi.org/10.1080/09583157.2010.534548

11. Maina, U. M., I. B. Galadima, F. M. Gambo \& D, Zakaria (2018). A review on the use of entomopathogenic fungi in the management of insect pests of field crops. Journal of Entomological and Zoological Studies .6, 27-32

12. Nguyen, H, Q., Quyen, D. T., Nguyen, S.L.T. \& Vu. V.H. (2015). An extracellular antifungal chitinase from Lecanicillium lecanii: purification, properties, and application in biocontrol against plant pathogenic fungi. Turkish Journal of Biology. 39, 6-14

13. Nirmala, R., Ramanujam, B. \& Rabindra, R. J. (2005). Growth parameters of some isolates of entomofungal pathogens and production of dust-free spores in rice medium. Journal of Biological control.19, 121-28

14. Palande, P. R. \& Pokharkar, D. S. (2005). Evaluation of Verticillium lecanii against Brevicornye brassicae on cole crops. Annals of Plant Protection Sciences. 13, 235-36

15. Joshi, R.N. \& Sangha, K. S. (2019). Effect of Adjuvants on $L$. lecanii against nymphs of $L$. erysimi. Indian Journal of Entomology, 81, 597-602

16. Silva, W. B., Mitidieri, S., Schrank, A. \& Vainstein, M. H. (2005).Production and extraction of an extracellular lipase from the entomopathogenic fungus Metarhizium anisopliae. Process Biochemistry. 40, 321-26

17. Singh, Harshdeep \& Joshi, Neelam (2020). Management of the aphid, Myzus persicae (Sulzer) and the whitefly, Bemisia tabaci (Gennadius), using biorational on capsicum under protected cultivation in India. Egyptian Journal of Biological Pest Control. 30, 67. doi:https:// doi.org/10.1186/s41938-020-00266-5

18. Somervaille, A, Gordon, B., Green, V., Burgis, M. \& Henderson, R. (eds). (2012). Adjuvants - Oils, surfactants and other additives for farm chemicals. Grains Research and Development Corporation, Australia Pp 1-52

19. Strauss, S. Y., Rudgers, J. A., Lau, J. A. \& Irwin, R. E. (2002). Direct and ecological costs of resistance to herbivory. Trends in Ecology and Evolution, 17, 278-85 
Thakur, K. et al. / J. Appl. \& Nat. Sci. 13(2), 530 - 536 (2021)

20. Sharma, T., Joshi, N. \& Kalia, A. (2017). Scanning electron microscopy of Beauveria bassiana against Lipaphis erysimi KALT. Journal of Applied and Natural Science, 9 (1), $461-465$.
21. Yadav, S. \& Kumar, V. (2021). Study of a prey-predator model with preventing crop pest using natural enemies and control AIP Conference Proceedings 2336, 020002 (2021) . doi: https://doi.org/10.1063/5.0045745 